\title{
Method of Circle Time In Developing Skills of Children Talking In Kindergarten
}

\author{
Syamsuardi $^{1}$, Hajerah $^{2}$ \\ \{Syamsuardi@unm.ac.id ${ }^{1}$, hajerah@unm.ac.id² \\ ${ }^{1,2}$ Universitas Negeri Makassar, Jl. AP. Pettarani, Makassar, Indonesia
}

\begin{abstract}
This study aims (1) method for learning the circle time method for learning in Kindergarten, (2) to know how to speak to children before and after treatment in kindergarten, (3) find out the circle time method influence children's speech skills in Kindergarten. The focus of this study is the application of the circle time method, and children's speaking ability. The results showed that the circle time method of learning activities was carried out in the good category. This means that there is an effect of applying the circle time method to the development of the children.
\end{abstract}

Keyword - Circle time, social interaction, speaking skills

\section{Introductions}

Education in early childhood according to Law No. 20 of 2003 was carried out by providing as much stimulus or stimulation as possible to children aged 0 to 6 years. The provisions of the stimulus are aimed at developing all of the child, such as the development of cognitive, physical-motoric, social, language, emotional and artistic aspects. Providing the right stimulus will make children grow and develop optimally, whereas the provision of stimuli that are less in accordance with the needs of children will have an impact on failure and needs of a child. Therefore, every educator or caregiver needs to understand the characteristics and needs of each student so that they can easily be available in each individual child.

Problems related to the development of children are currently the main topic of each discussion in the PAUD forum. One of the main problems that are more inclined to individual and passive forms of play such as the use of games that are packaged in devices such as gadgets and smartphones. Children's interest in gadgets and smartphones have an impact on the lack of social interaction of children and also have an impact on the development of children's speaking abilities. Moreover, the introduction of gadgets and smartpohone games actually happened during the early development period of children before entering kindergarten education, namely in family education (informal). The main reason for this is the fact that it is a tendency for parents to use gadgets and a smartphone that is upset and angry. The condition that lasts as long as the child is in family education makes it an important factor in developing children's speaking skills (Syamsuardi, 2015).

The importance of developing the children's speaking skills (Ahmad Susanto, 2011) is needed as a tool to communicate with the environment, as a tool to develop children's intellectual abilities, as a tool to develop children's expressions, and as a tool to express feelings and thoughts to others. In addition, the development of speaking skills is used by children to express their desires, needs, thoughts, and feelings to others. Cues, emotional expressions, speech or written language that can be used in the process of exchanging thoughts and feelings. However, speaking is the most common and most effective form of 
communication, especially for the category of early childhood (Hurlock, 1978). By him, in developing it needs to be considered as well as models and opportunities to practice. A good model for emulating is needed so that children know to pronounce word correctly. These models may be people in the environment around them. If they lack a good model, then they will find it difficult to speak and the results achieved are below their abilities. Opportunities to practice, they will despair and motivate children to be low to play roles in real life situations and practice skills help can improve the children's speaking skills.

Cita Masamba kindergarten students, where they are based on a variety of ways to improve the health of their children. children's interest in playing individual games. such as the use of gadgets and smartphones. Moreover, parents acknowledge that giving children gadgets and smartphones is an effective way to calm children when parents are busy working. What's more, parents don't understand about the risks of using technology and smartphones to impact that is disadvantaged for children's development.

By him, kindergarten as a place to maximize the children's potential needs to be aware of the forms of family education that deviate from actual education. By the necessity, kindergarten becomes a place in reconstructing all the less developed potential in education in the family environment, especially in the development of speaking skills. One form of game that can be used by applying the circle time method. The application of this method focuses on how children engage in social interactions with people who have an impact that can support the development of children's speaking skills. Meanwhile, from the results of the preliminary observations, the researchers showed the application of the activities of the Insan Cita Kindergarten, Masamba was more inclined to use the method and conversing in simple and final activities and was not familiar with the circle time method.

The circle time method in Florida, USA which is packaged in Beyond Center and Circle Time (BBCT) is one method that has a child-centered concept, where the circle is done at the beginning or end of core learning. Although the implementation of activities in this method is almost the same as the conversation method, the level of development of children and the right time in developing children's abilities can focus on their interests and needs. This learning method is known as child centered learning which the learning process is centered in the center of play and when children form a circle, while the teacher has a role to facilitate, motivate and evaluate. Circle Time is a group activity carried out by a number of people consisting of adults and children, together with the aim of building mutual understanding. As for adults who are involved in circle time activities, who are deliberately brought in to discuss children based on topics or themes that have been determined (Luluk Asmawati, 2012: 7.5). In line with that expressed by Masitoh and Djoehaeni, 2005) that, "the circle time is a learning method that can be used in a kindergarten by making a semicircular formation where teachers and children can interact directly". This method provides as many opportunities as possible for express ideas or satisfy their curiosity.

The implementation of the aims to develop the circle time learning method is that the teacher needs knowledge in accordance with the predetermined theme. The implementation of this method is carried out in accordance with the procedures made by Masitoh and Djoehaeni (2005: 214-215) which consists of three stages, namely the preparation stage, the implementation phase, and the closing stage. a) Preparation phase, at this stage the teacher prepares the class setting by arranging the position of the child in a circle. The teacher also prepares facilities and media to be used in learning activities. The media that will be used is adjusted to the predetermined theme. b) The implementation stage, the conversation starts at this stage. The teacher provides the widest opportunity for children to express their opinions but still in accordance with the predetermined theme. The teacher provides answers or 
questions that have been prepared beforehand. c) The closing stage, this stage the teacher draw conclusions or re-explains the activities that have been carried out that day. The teacher can do a question and answer to the reminders of the children in the previous activity.

From the description above, the study leads to the use of the circle time method in developing children's speaking skills, so that the tendency for children to play can be changed towards more active games through increasing children's interaction in play.

\section{Method}

The approach of this research is a type of research using the pre-experiment of the one group pretest-posttest design. This study involved one experimental group selected by purposive sampling consisting of 1 teacher and 13 students from the Insan Cita Kindergarten in Masamba District, North Luwu Regency. The research began with the initial test (pretest), then the treatment (treatment) and ended with the final test (posttest). The aim is to collect data about the influence of the circle time method on the children's speech abilities.

Data collection techniques for uncovering data on children's abilities before and after treatment, observations are made to reveal data on teacher and student activities during treatment, and documentation. The data analysis technique that has been obtained is processed using descriptive and inferential statistical analysis. Descriptive statistics are intended to provide overview of the implementation of the treatment both before and after being treated and hypothetically tested using the inferential Wilcoxon test with a significant level of $\alpha=0$, 05 .

\section{Result and Discussion}

Based on data obtained in the field before the child is treated by using the circle time method. In general, it is presented in the form of a frequency distribution table which is classified into three categories, namely good, sufficient, and lacking. The following data before treatment (pretest) and data after treatment (Posttest).

Table 1. Percentage of Speaking skills of Children Before Treatment (Pretest)

\begin{tabular}{|c|c|c|c|}
\hline Interval & Category & Frekuensi & Presentase \\
\hline $15-18$ & Good & 1 & $7 \%$ \\
\hline $11-14$ & Enough & 7 & $54 \%$ \\
\hline $6-10$ & Less & 5 & $39 \%$ \\
\hline
\end{tabular}

From the data above, the results of the initial test before treatment showed a percentage of $7 \%$ of students' speaking skills were very low in the category. Child speaking skills with a percentage of $39 \%$.

Table 2. Percentage of Ability to Speak Children After Treatment (Posttest)

\begin{tabular}{|c|c|c|c|}
\hline Interval & Category & Frekuensi & Presentase \\
\hline $15-18$ & Good & 9 & $69 \%$ \\
\hline $11-14$ & Enough & 4 & $31 \%$ \\
\hline $6-10$ & Less & 0 & $0 \%$ \\
\hline
\end{tabular}




\begin{tabular}{|c|c|c|c|c|c|c|}
\hline \multirow{2}{*}{ No } & \multirow{2}{*}{ Name } & \multirow{2}{*}{ BT (Xi) } & \multirow{2}{*}{$\mathbf{A T}(\mathbf{Y} \mathbf{i})$} & \multirow{2}{*}{$\begin{array}{c}\text { Different } \\
\text { (Yi-Xi) }\end{array}$} & \multicolumn{2}{|c|}{$\begin{array}{l}\text { Level } \\
\text { mark }\end{array}$} \\
\hline & & & & & + & - \\
\hline 1 & FA & 11 & 16 & -5 & & 12,5 \\
\hline 2 & SD & 14 & 13 & 1 & 1,5 & \\
\hline 3 & AS & 14 & 17 & -3 & & 3,5 \\
\hline 4 & NA & 12 & 16 & -4 & & 8 \\
\hline 5 & $\mathrm{NH}$ & 14 & 17 & -3 & & 3,5 \\
\hline 6 & DA & 12 & 16 & -4 & & 8 \\
\hline 7 & $\mathrm{AG}$ & 9 & 14 & -5 & & 12,5 \\
\hline 8 & SS & 15 & 16 & -1 & & 1,5 \\
\hline 9 & RO & 13 & 17 & -4 & & 8 \\
\hline 10 & $\mathrm{HE}$ & 12 & 16 & -4 & & 8 \\
\hline 11 & AW & 9 & 13 & -4 & & 8 \\
\hline 12 & YU & 10 & 14 & -4 & & 8 \\
\hline 13 & $\mathrm{AZ}$ & 12 & 16 & -4 & & 8 \\
\hline \multicolumn{2}{|c|}{ Jumlah } & 157 & 201 & & 1,5 & 95 \\
\hline
\end{tabular}

Table 3. Percentage of Speaking skills of Children Before Treatment (Pretest) and After Treatment (Posttest)

After giving a treatment for several times by using the circle time method by focusing on developing children's speaking skills, the data on improving children's skills has a significant increase in the category with a percentage of $69 \%$, while the category suffers a decrease in value with a percentage of $31 \%$, there are no more who have skills speaking in the less category.

BT (before treatment)

AT (after treatment)

From the table above, the number of levels is marked $(+)=1.5$ and the number of levels marked $(-)=77$. In the decision making in the Wilcoxon test, the $\mathrm{T}$ value to be tested is smaller $\mathrm{T}$ value so $\mathrm{T}=1,5$. Then the value of tcount $=-3,076$ is obtained. If the error level is 0.05 then the price is $t$ table $=1.645$. Because thitung $=-3,076$ can be $t$ table $=1,645$, then Ho is rejected. This means that there is a circle time method on the development of the children's speaking skills at Cita Masamba Insan Kindergarten.

The results of the research were conducted in the Kindergarten of the Society of Masamba, North Luwu Regency, including: 1) the preparation stage, at this stage the teacher prepares class adjusting the sitting position children form a circle. The teacher also prepares facilities and media that will be used in learning activities in Kindergarten, the theme of my needs is to determine the media to be adjusted to the theme of my predetermined needs, 2) the implementation stage, the implementation of the stage the teacher starts the conversation at the stage, then the teacher gives a response to or question or answer given by the child and confirms information using a tool or media that has been prepared beforehand, and 3) the 
stage evaluation, this stage the teacher draw conclusions or the activities that have been carried out that day. The teacher conducts a question and answers the session to remind what the children are revealed in the previous activity.

The application of circle time learning model through giving children the opportunity to interact more by forming a circle is able to develop children's speaking skills well because the process of implementing the circle time method starts with the initial footing and the final step after the play is finished. Dini (2006) provides an illustration of the application of circle time or when a circle is marked by the initial foothold given before and after play and learning which is done in a circular format or setting. The implementation of the credit time method leads the child to an active form of play especially in developing the ability to express opinions, confidence and build self-awareness in providing opportunities for his peers to speak. This is in line with Greenberg's opinion (Hartati, 2005: 29) that, "learning can be effective if we are working, playing and living together with their environment." So, learning for children is an experience that is meaningful and is an opportunity to create, imagine, and express all their ideas.

This study shows the circle time method is one of the learning models that can be recommended because it is in accordance with the developmental stages in children. So far, in general, the implementation of learning skills is more focused on basic skills such as memorization, the ability of balancing, where the process neglects the stages of child development (Early, 2006). The results of this study also revealed that the circle time method has a role in developing aspects of talking to children. This wish is an opportunity to express their wishes. Actually, as a starting point and final activity as a reinforcement of each learning meeting so that children understand what they are doing and what they have done. In this stage, the teacher facilitates the child to communicate. Every child is given more communication. This is the line with opinion expressed by Kustanti, 2004: 19) that, "speaking skills are obtained from everyday life".

The based on the inferential test results obtained by the circle time method have been conducted by the Wilcoxon test which is done by comparing the significant significant (Sig) with alpha $(\alpha)$ with significant value testing criteria $(0,000)<$ alpha $(0.05)$ which shows that the circle of time is in a circle time method for dealing with speaking Insan Cita, Masamba District, North Luwu Regency. The improvement of the most important questions, including children able to answer more complex questions, communicate verbally, have vocabulary, arrange simple sentences in complete structure (main sentence-description), choose more words and vary to express ideas to others and continue some stories / tales that have been heard.

\section{Conclusion}

Based on the results of research and discussion, the conclusions of this study are:

1. In order to be active in the game, teacher and student experience that is new to the circle time method, and the availability of game media that supports the circle time method is still lacking.

2. The ability to speak to children before use of the circle time method is dominated by less categories. This is a significant increase after being treated.

3. There is a positive influence on the circle time method for children's speaking ability in Cita, Bone Village, Masamba District, North Luwu Regency 


\section{Acknowledgements}

Our appreciation for Early Childhood Education Teacher Education Study Program, Faculty of Education, Makassar State University for their support in this research.

\section{References}

[1]. Ahmad Susanto, 2011. Perkembangan anak usia dini: pengantar dari berbagai aspeknya. Kencana, Jakarta.

[2]. Ardy Novan, B. (2012). Format PAUD.

[3]. Asmawati, Luluk. Dkk. 2012. Pengelolaan Kegiatan Pengembangan Anak Usia Dini. Banten: Universitas Terbuka

[4]. Coy, G. D., \& Vos, J. (2001). Revolusi Cara Belajar. Bandung: Kaifa.

[5]. Coremap. 2011. Mengapa Kita Berkomunikasi (Online). Diakses pada 4 Februari 2012.

[6]. Dhieni. 2008. Metode Pengembangan Bahasa. Jakarta: Universitas Terbuka.

[7]. Dini, D.P.A.U., 2006. Pedoman Penerapan Pendekatan "Beyond Centers And Circle Time (BCCT)"(Pendekatan Sentra Dan Lingkaran) Dalam Pendidikan Anak Usia Dini. Jkt. Dep. Pendidik. Nas.

[8]. Fitriani, Y., \& Isyam, A. (2012). The use of BCCT (Beyond Centre and Circle Time) Approach to Teach English Vocabulary to Kindergarten's Pupils. Journal of English Language Teaching, 1(1), 246-254.

[9]. Hartati, S., 2005. Perkembangan belajar pada anak usia dini. Jkt. Depdiknas.

[10]. Hadisukanto, Gitayanti. 2013. Dampak Buruk Gadget Pada Kemampuan Bicara Anak (Online). https://www.viva.co.id/gaya-hidup/parenting/897279-dampak-buruk-gadgetpada-kemampuan-bicara-anak

[11]. Hurlock, E.B., 1978. Jilid 1. perkembangan anak edisi keenam (Med. Meitasari Tjandrasa. Terjemahan). Jkt. Erlangga Buku Asli Diterbitkan Tahun.

[12]. Kustanti, D., 2004. Metode Pengajaran di Taman Kanak-Kanak. Jakarta: Rineka Cipta.

[13]. Masitoh, O.S., Djoehaeni, H., 2005. Pendekatan belajar aktif di taman kanak-kanak. Jkt. Dep. Pendidik. Nas.

[14]. Masrurah, F. (2014). KECERDASAN VERBAL-LINGUISTIK ANAK MELALUI PENDEKATAN BEYOND CENTERS AND CIRCLE TIME (BCCT). Lisan al-Hal: Jurnal Pengembangan Pemikiran dan Kebudayaan, 6(2), 305-334.

[15]. Musi, M. A., \& Winata, W. (2017). Efektivitas Bermain Peran Untuk Pengembangan Bahasa Anak. PEMBELAJAR: Jurnal Ilmu Pendidikan, Keguruan, dan Pembelajaran, 1(2), 93-104.

[16]. Rindaningsih, I. (2012). Pengembangan Model Manajemen Strategik Berbasis (beyond center and circle Time) BCCT Pada PAUD. PEDAGOGIA: Jurnal Pendidikan, 1(2), 213-223.

[17]. Nurhaedah, N., \& Amal, A. (2017, October). Model Pembelajaran High/Scope dalam Menumbuh Kembangkan Kemampuan Anak Usia Dini. In Seminar Nasional Lembaga Penelitian UNM (Vol. 2, No. 1).

[18]. Sudjana, N., \& Rivai, A. (2005). Media Pengajaran, bandung PT Sinar Baru Algesindo.

[19]. Sudrajat, A. (2008). Pengertian pendekatan, strategi, metode, teknik, taktik, dan model pembelajaran. Online)(http://smacepiring. wordpress. com).

[20]. Sugiyono, M. P. P. (2007). Pendekatan Kuantitatif. Kualitatif, dan R\&D, Bandung: Alfabeta. 
[21]. Syamsuardi, 2015. Speech Delay and Its Affecting Factors (Case Study in a Child with Initial Aq). J. Educ. Pract. 6, 68-71. 
